\title{
Adoption and farm-level impact of conservation agriculture in Central Ethiopia
}

\author{
Wondwossen Tsegaye ${ }^{1} \cdot$ Roberto LaRovere $^{2} \cdot$ Germano Mwabu $^{3}$ • \\ Girma T. Kassie ${ }^{4}$
}

Received: 15 May 2015/ Accepted: 15 October 2016

(C) Springer Science+Business Media Dordrecht 2016

\begin{abstract}
Soil erosion and degradation is an important agro-ecological challenge in the highlands of Ethiopia. Conservation agriculture (CA) has a long time been identified as one of the key interventions that could abate the current trend of physical and chemical erosion of soil. This study analyzed adoption of the different components of CA (minimal disturbance of soil, permanent organic soil cover, and crop rotation) and herbicide application in two districts of Ethiopia using a multivariate probit model. The impact of CA on land and labor productivity was also estimated using generalized methods of moments and the control function approach. The initial decision to adopt the different components of CA is influenced by location, family size, access to extension, and formal education. Among the components introduced with CA, herbicide application significantly and strongly influences land productivity. Other factors, which influenced land productivity, were location, sex of head of household, livestock wealth, and human labor endowment. None of the components of $\mathrm{CA}$-including the complementary herbicide application-was found to be influencing labor productivity in the study areas. Generally, access to extension and the main crop under production drive the decision to adopt or not to adopt the different components of CA. Despite its positive impact on land productivity, herbicide application
\end{abstract}

Girma T. Kassie

g.tesfahun@cgiar.org; girmatesfa@yahoo.com

Wondwossen Tsegaye

wendsentsgay@yahoo.com

Roberto LaRovere

roberto.larovere@gmail.com

Germano Mwabu

gmwabu@gmail.com

1 SG 2000/CIMMYT, Addis Ababa, Ethiopia

2 UNDP, New York, NY, USA

3 University of Nairobi, Nairobi, Kenya

4 ICARDA, Addis Ababa, Ethiopia 
should be further investigated with attention to its effect on sustainable use of cultivable land.

Keywords Conservation agriculture $\cdot$ Control function · Impact · Multivariate probit

JEL Classification Q12 - Q16

\section{Introduction}

Low land productivity mainly due to land degradation and inefficient use of water resources characterizes Ethiopian agriculture. It is estimated that the country loses at least 13,000 tons of soil $/ \mathrm{km}^{2} /$ year from its cropland and an average of 3500 tons $/ \mathrm{km}^{2} /$ year from its highlands (Berry 2003; Tamene and Vlek 2008). This translates to over 0.27 million $\mathrm{km}^{2}$ already eroded and over 0.02 million $\mathrm{km}^{2}$ beyond reclamation (Berry 2003). Land degradation in Ethiopia has been aggravated mainly by overpopulation, frequent soil tillage, inefficient crop and livestock production system, and soil erosion (Hawando 2000; Jolejole-Foreman et al. 2012). Majority of Ethiopians ( $~ 80 \%)$ depend directly or indirectly on agriculture for their livelihoods. Therefore, reduction in soil fertility and soil quality strongly contributes toward the deprivation and deterioration of the rural livelihoods in the country. In addition to the reduction in soil quality, the insufficient and erratic rainfall patterns challenge the performance of agriculture in many areas across the country (Araya et al. 2010).

The inefficiency in soil and water resource use is so significant that the country is unable to produce enough grains to feed its population even in seasons of normal rainfall (Kassa 2003). National domestic grain production is estimated to account only for about $70 \%$ of the total food requirement. Hence, each year, four to six million people need food assistance despite the existence of potentially productive resources for food self-sufficiency and even surplus production (EEA 2006). The country's crop farming is predominantly operated by smallholder farmers, practicing traditional plow (Maresha)-based (with draft animals) activities. Scientific research has well documented that conventional farming with frequent tillage gradually degrades the physical structure and chemical quality of tropical soils (Brady and Weil 2007). This dire situation has prompted the government and other key stakeholders within Ethiopian agriculture to identify and implement alternative farmlevel practices that enhance productivity without undermining the natural resources, particularly cropland.

Conservation agriculture (CA) is a notable approach for managing agro-ecosystems for improved and sustained productivity, increased profits and food security while preserving and enhancing the land-resource base and the environment (FAO 2016). Conservation agriculture was one of the technologies introduced in Ethiopia to abate deterioration of soil and water resources in the late 1990s. In practice, CA involves the simultaneous application of minimal soil disturbance, retention of crop residues as mulch on the soil surface, and the use of crop rotations and/or associations (Corbeels et al. 2014; FAO 2016; Giller et al. 2009). The concept of CA also aggregates a number of soil and water management and conservation practices under a single banner for delivery to farmers (Garcia-Torres et al. 2003; Knowler and Bradshaw 2007).

Conservation agriculture practices are increasingly promoted on smallholder farms in sub-Saharan Africa as a means to overcome continuing poor-profitability and soil 
degradation (Corbeels et al. 2014). Complemented by other known good practices, including the use of quality seeds, and integrated pest, nutrient, weed and water management, CA is a base for sustainable agricultural production intensification (FAO 2016). In the process of adapting CA to different contexts, different practices have been included, such as integrated pest management (Leake 2003), planting of perennial legume trees (Mowo and Kiwia 2009), construction of runoff harvesting furrows (Oicha et al. 2010), manure and inorganic fertilizer applications (Mazvimavi and Twomlow 2009). In Ethiopia, Sasakawa Global 2000 (SG-2000) ${ }^{1}$ introduced CA in 1998. Demonstration of CA was first conducted on 77 maize plots in Central Ethiopia, and by 2008, the technology had reached more than 16 districts. The number of farmers who have started using CA in Central Ethiopia had reached 3047 by 2011, from just only 262 farmers in 2006. Currently, SG2000 has promoted CA in over 35 districts, and learning from its experience, governmental agencies (e.g., Ethiopian Agricultural Transformation Agency), and nongovernmental organizations [e.g., sustainable land management (SLM) and self-help groups] are promoting CA in many parts of the country. With intensive and practical training to the government extension personnel, SG-2000 managed to promote the technology throughout the country as the public extension has taken up the technology as one of its sustainable soil management technology packages. After initial on-farm demonstrations with the three components/principles, SG-2000 decided to complement CA with herbicide application to address the weed challenge that the potential adopters of CA were facing. Therefore, CA has always been demonstrated and disseminated in Ethiopia with herbicide application as an indispensable component of this technology.

Although soil and water conservation practices, including minimum or no-tillage, have long been practiced by farmers in Ethiopia, CA was introduced in 1998 by SG-2000 on 77 maize plots in Central Ethiopia (Matsumoto et al. 2004). Working closely with the Ministry of Agriculture, SG-2000 managed to disseminate CA technology in many parts of the country. The interventions initially concentrated in central highlands of Ethiopia

Despite the decade old national effort to systematically disseminate CA, very limited empirical evidence has been presented as to what extent the technology is being adopted, or the extent to which farm yields are being influenced. Only a few studies (Kassie et al. 2009; Oicha et al. 2010; Rockstrom et al. 2009; Shames 2006) have reported on the status and effects of CA in the country. These studies focused on northern Ethiopia where drought and soil degradation are still the most important agricultural constraints. A study by Kassie et al. (2009) analyzed the adoption decision of minimum tillage, compost, and chemical fertilizer using a trivariate probit model and reported evidence of variability at household level with regard to the factors that influence adoption decisions of the three practices.

Similarly, Rockstrom et al. (2009) presented results of on-farm trials that showed increased yields and improved water productivity using CA in semiarid and dry subhumid locations in Ethiopia, Kenya, Tanzania, and Zambia. They identified challenges for the adoption of CA in sub-Saharan Africa including ways to improve farmer awareness of CA benefits and ways to efficiently incorporate green manure/cover crops and management of weeds. Oicha et al. (2010) studied tef (Eragrostis abyssinica) farms under traditional tillage practice (TRAD), traditional furrow-based water conservation (TER), and

\footnotetext{
1 Sasakawa Global 2000 is a global initiative, and its Ethiopian program was established in 1993 as an "implant" into the national agricultural extension system with the purpose of introducing new approaches to extension in order to increasing farm-level productivity, especially of smallholder farmers. See http:// sg2000ethiopia.org/\# for further details.
} 
permanent beds (PB) in northern Ethiopia and reported that yield, biomass, and plant height of tef were significantly higher in TRAD than in PB. Araya et al. (2015) conducted a study on permanently kept rainfed experimental Vertisol plots to compare CA that integrated in situ soil and water conservation tillage practices and a conventional system. Crop yield was one of their comparison yardstick, and they concluded that field water conservation tillage practices that incorporate $\mathrm{CA}$ improve crop productivity and yield substantially on Vertisols in drylands without other inputs.

This study builds on lessons learned so far and intends to inform policy makers about interventions that would influence adoption of CA in ways that will significantly change livelihoods. None of the previous studies has addressed the adoption of complementary components of CA, including effects on land or labor productivity. This study fills an important gap in this regard, not only in terms of covering a new geographical area, but also in showing how impacts of CA on both labor and land use can be robustly estimated.

\section{Methodology}

\subsection{The Study Area}

This study was conducted in Bakko Tibe and Ada'a Chukala districts of Central Ethiopia (Fig. 1a, b). These two sites were selected out of the nine districts where, since 1998, SG2000 has been promoting CA technologies on maize (Zea mays) and tef. Bakko Tibe District is located $250 \mathrm{~km}$ west of Addis Ababa and has an average altitude of 1700 masl (meters above sea level) and an average annual rainfall of $1267 \mathrm{~mm}$ with unimodal distribution. It is situated at $9^{\circ} 00^{\prime} \mathrm{N}$ latitude and $37^{\circ} 10^{\prime} \mathrm{E}$ longitude. The district is located within the maize production belt of Ethiopia and is considered to be one of the major maize-producing areas in the country. Other important crops grown in the district are sorghum (Sorghum bicolor) and tef. Owing to its potential for crop production, the district has relatively high rates of adoption of improved agricultural technologies including fertilizer and new varieties (Gemeda et al. 2001). Crop production is adversely affected in this area by serious soil degradation, reduction of draft power as a result of animal disease, erratic rainfall, flooding, and unaffordable high input prices. Different interventions have been made to enhance agricultural production and productivity, and CA is one of them.

Ada' a Chukala is the other study district located $47 \mathrm{~km}$ East of Addis Ababa, at an average altitude of 1900 masl and annual average rainfall of $850 \mathrm{~mm}$ with bimodal distribution. Geographically, Ada'a is positioned at $8^{\circ} 47^{\prime} \mathrm{N}$ latitude and $38^{\circ} 57^{\prime} \mathrm{E}$ longitude. Ada'a Chukala is known for its high-quality tef although farmers grow wheat (Triticum spp.), maize, and beans (Phaseolus vulgaris) to a limited extent as well. Agricultural productivity in the district is affected by soil degradation, high cost of farm inputs and animal feed, shortage of land, and monocropping. Like Bakko, Ada'a Chukala is one of the districts where SG-2000 initially started implementing CA.

\subsection{Sample Size and Survey Methods}

In each of the districts, two Kebeles ${ }^{2}$ were chosen from a cluster of areas where farmers were practicing CA and had functioning farmers' cooperatives. Then, households were selected using random sampling proportionate to the total number of households in each

$\overline{{ }^{2} \text { Kebele (pl. Kebeles) is the smallest administrative unit in Ethiopia. }}$ 
(a)

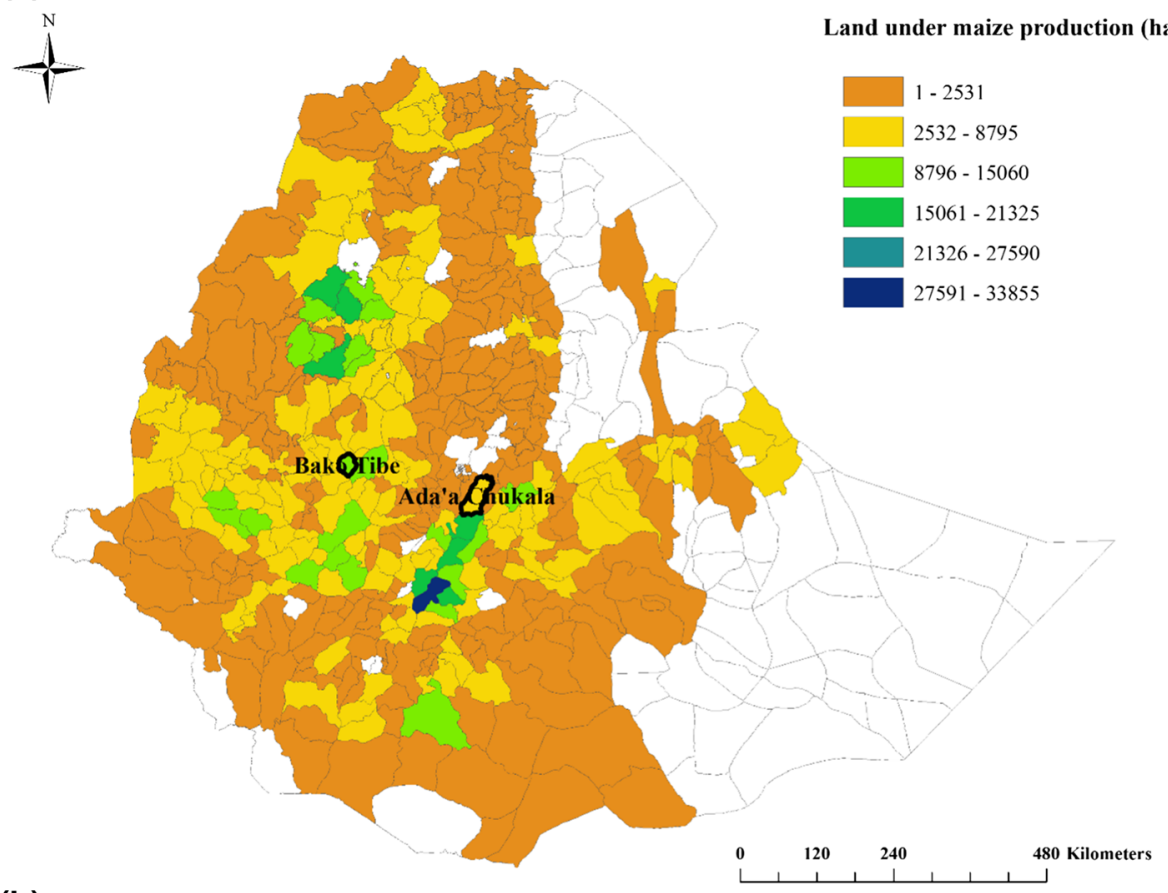

(b)

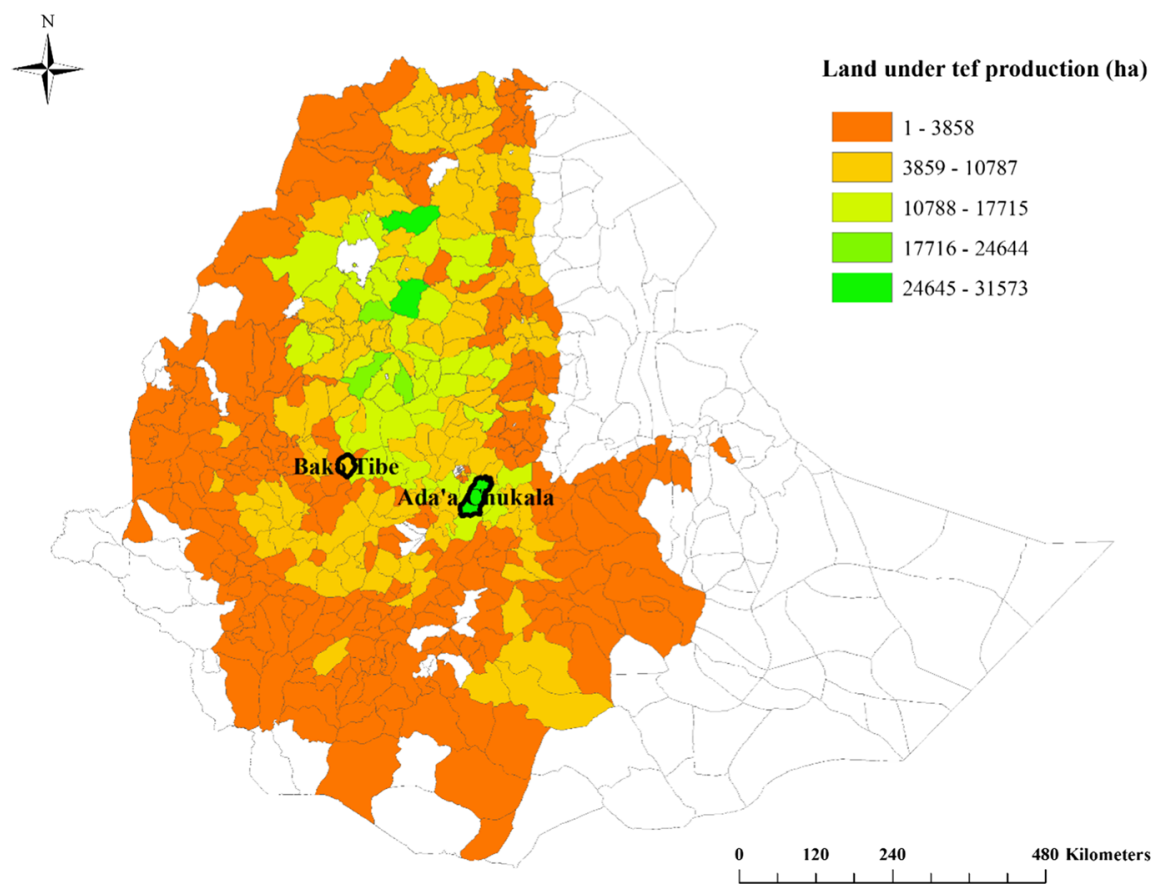

Fig. 1 a Land under maize production (hectares) and location of Bakko Tibe and Ada'a Chukala districts, b land under tef production (hectares) and location of Bakko Tibe and Ada'a Chukala districts 
kebele; the final sample included 124 households from Bakko Tibe and 71 from Ada'a Chukala. Cross-sectional data were collected on different variables including household demographics, land use, input use, crop harvests, the adoption of CA components, livestock, assets wealth, income and expenditure, distance to local markets, access to extension services, and labor using structured questionnaires.

\subsection{Analytical Framework}

Decisions on adopting a technology involve identifying and selecting use of a bundle of innovations rather than just a single element of productivity-enhancing factors (Becerril and Abdulai 2010). The productivity-improving effect of each of the components may not be realized if farmers decide to adopt a part, rather than the whole of the recommended package of a technology (Karanja et al. 2003).

The empirical studies on CA in Ethiopia (Kassie et al. 2009), or Africa (Haggblade and Tembo 2003; Mazvimavi and Twomlow 2009) in general, show that farmers tend to adopt only some of the components - usually minimum tillage complemented by higher quantity of herbicides at the initial stages. Farmers rarely adopt all the components of CA at a time. Nonetheless, use of all components is advised to reap the full benefits of the new technology over conventional farming (Dumanski et al. 2006; FAO 2001; Ito et al. 2007).

A given farm household would be adopting one or more of the components of CA if and only if the benefit expected is higher than otherwise. The decision to adopt a component is related to the same decision on other components of the technology. This is because farmers are choosing among the different components of CA implying interrelationships of the unobserved factors that influence the adoption decisions. Failure to capture unobserved factors and interrelationships among adoption decisions regarding different practices will lead to bias and inefficient estimate (Belderbos et al. 2004).Consequently, the multivariate probit model is employed to analyze the interrelated decisions of adopting each of the components of CA. In contrast to multivariate probit models, univariate probit or logit models ignore the potential correlation among the unobserved disturbances in the adoption equations as well as the relationships between the adoptions of different components of CA. The multivariate probit model simultaneously accounts for the influences of the set of explanatory variables on each of the different practices while allowing the unobserved and unmeasured factors (error terms) to be freely correlated (Belderbos et al. 2004).

Both SG-2000 and public extension officers advise farmers to (1) leave a minimum of $30 \%$ mulch cover on the land to build and maintain organic matter in the soil; (2) practice crop rotations to control pests, weeds, and other biotic factors that adversely affect crops; (3) practice minimum or no-tillage to decrease soil erosion and conserve labor; and gradual reduction of the use of herbicides as CA practice is adopted (Ito et al. 2007). The observations in the field showed, however, that crop rotation is a common practice farmers undertake both for pest/disease and for soil fertility management. This analysis therefore focuses on the other two components of CA and herbicide application.

The multivariate probit model (Greene 2008; Train 2003) was estimated to analyze the adoption decisions, and it is specified as follows. Let $\mathrm{Y}_{\mathrm{ij}}$ denote a binary response on the $i$ th individual $(i=1,2, \ldots, N)$ unit and $j$ th variable $(j=1,2, \ldots, P)$, and let $\mathrm{Y}_{\mathrm{i}}=\left(Y_{i 1}, \ldots\right.$, $\left.Y_{i P}\right)^{\prime}$ denote the collection of responses on all $P$ variables. Let $Z_{i}=\left(z_{i l}, \ldots, z_{i P}\right)$ denote a $p$ variate latent variable that is normally distributed with a mean vector $\boldsymbol{\beta} \mathbf{x}_{i}$ and variancecovariance matrix $\boldsymbol{\Sigma}$, where $\mathbf{x}_{i}=\left(x_{i 1}, \ldots, x_{i, q}\right)^{\prime}$ is a $q$-vector of covariates and $\boldsymbol{\beta}=\left(\boldsymbol{\beta}_{1}, \ldots\right.$, $\boldsymbol{\beta}_{q}$ ) is a $p \times q$ matrix of regression coefficients of $\mathbf{z}$ on $\mathbf{x}$. The observed binary vector $\mathbf{y}_{i}$ is associated with the underlying $\mathbf{z}_{i}$ in the following way $y_{i j}=\boldsymbol{I}\left(z_{i j}>0\right), j=1,2, \ldots, p$, 
where $I(\cdot)$ is an indicator function. Therefore, the probability that $Y_{i}=y_{i}$, given the covariates $\mathbf{x}_{i}$ and the parameters $\boldsymbol{\beta}$ and $\boldsymbol{\Sigma}$, is

$$
P\left(y_{i} \mid x_{i}, \beta, \Sigma\right)=\int_{B_{i 1}} \ldots \int_{B_{i p}} \phi_{p}\left(t ; \beta x_{i}, \Sigma\right) \mathrm{d} t
$$

where $\phi_{p}\left(\mathbf{t} ; \boldsymbol{\beta} \mathbf{x}_{i}, \mathbf{\Sigma}\right)$ is the density of a $p$-variate normal distribution with mean vector $\boldsymbol{\beta} \mathbf{x}_{i}$ and variance-covariance matrix $\boldsymbol{\Sigma}$. The interval $B_{i j}$ is $(-\infty, 0]$ if $y_{i j}=0$ and $(0, \infty)$ if $y_{i j}=1$.

However, the parameters $\boldsymbol{\beta}$ and $\boldsymbol{\Sigma}$ are not identifiable according to the observed-data likelihood (Chib and Greenberg 1998). For any diagonal matrix D with positive diagonal elements, it can be shown that

$$
P\left(\mathbf{y}_{\mathrm{i}} \mid \mathbf{x}_{\mathbf{i}}, \boldsymbol{\beta}, \mathbf{\Sigma}\right)=P\left(\mathbf{y}_{\mathrm{i}} \mid \mathbf{x}_{\mathbf{i}}, \mathbf{D} \beta, \mathbf{D} \Sigma \mathbf{D}\right)
$$

This implies that the variances in the matrix $\boldsymbol{\Sigma}$ cannot be estimated based on the likelihood function. For simplicity, we set them to be unity. Thus, the variance-covariance matrix $\boldsymbol{\Sigma}$ is restricted to be a correlation matrix $\mathbf{R}=\left(\rho_{i j}\right)$.

Augmenting the observed binary data $\mathbf{y}=\left[\mathbf{y}_{1}, \mathbf{y}_{2}, \ldots, \mathbf{y}_{N}\right]$ with the latent variables $\mathbf{z}=\left[\mathbf{z}_{1}, \mathbf{z}_{2}, \ldots, \mathbf{z}_{N}\right]$, the complete-data likelihood function can be written as

$$
\begin{aligned}
L_{\mathrm{com}}(\theta \mid \mathbf{y}, \mathbf{z})= & (2 \pi)^{-\frac{N p}{2}}|\mathbf{R}|^{-\frac{N}{2}} \exp \left[-\frac{1}{2} \operatorname{tr}\left\{\mathbf{R}^{-1} \sum_{i=1}^{N}\left(\mathbf{z}_{\mathbf{i}}-\beta \mathbf{x}_{\mathbf{i}}\right)\left(\mathbf{z}_{\mathbf{i}}-\beta \mathbf{x}_{\mathbf{i}}\right)^{\prime}\right\}\right] \\
& \times \prod_{i=1}^{N} \prod_{j=1}^{P} I\left(z_{i j} \in B_{i j}\right)
\end{aligned}
$$

where $\boldsymbol{\theta}$ denotes the model parameters $\boldsymbol{\beta}$ and $\rho_{i j}$ 's. Integrating over $\mathbf{z}_{i}$ 's in (3) yields the observed-data likelihood of the MP model,

$$
L_{\mathrm{obs}}(\theta \mid \mathbf{y})=\prod_{i=1}^{N} P\left(\mathbf{y}_{\mathbf{i}} \mid \mathbf{x}_{\mathbf{i}}, \beta, \mathbf{R}\right)
$$

The estimation was done using the user-written mvprobit Stata ${ }^{\circledR}$ procedure (Cappellari and Jenkins 2003) which employs the Geweke-Hajivassiliou-Keane smooth recursive conditioning simulator to evaluate the multivariate normal distribution (Train 2003). The GHK simulator was indicated to have desirable properties in the context of multivariate normal limited dependent variables that the simulated probabilities are unbiased, they are bounded within the $(0,1)$ interval, and the simulator is a continuous and differentiable function of the model's parameters.

\subsection{Modeling Impacts of CA on Land and Labor Productivity}

The impacts of the adoption of the CA technology are studied by estimating structural models of crop yields per hectare and labor productivity, taking into account the estimation problems of endogeneity and heterogeneity. Following Wooldridge (2002), the structural models are formulated as follows:

$$
y=z_{1}^{\prime} \delta_{y}+\sum x^{\prime} \beta+v_{1}
$$




$$
x=z^{\prime} \delta_{x}+v_{2}
$$

where $y$ denotes the outcome variable of interest, which in this case is crop yield per unit of land (land productivity) and per unit of labor (labor productivity); $x$ denotes endogenous regressors; $z$ denotes an exogenous set of variables and contains $z_{1}$ variables that are also part of the outcome equation, plus a vector of instruments, i.e., exclusion restrictions, defined as exogenous variables that affect each of the endogenous regressors $(x)$, but have no direct influence on the outcome variables. The parameters $\beta$ and $\delta$ are vectors of coefficients to be estimated, and $v$ is a disturbance term.

Using the above equations the parameters of interest can be estimated using the instrumental variables (IV) method. To use the IV approach, the set of exclusion restrictions, $z$, must satisfy two conditions. First, $z$ must be uncorrelated with $v_{1}$, that is, it influences the endogenous variable(s) but has no direct effect on land or labor productivity. The second requirement relates to the linear projection of $x$ onto the entire set of exogenous variables as shown in Eq. (6) where the error term, $v_{2}$, is uncorrelated with $z$ and also where the coefficients on $z$ are nonzero.

Although the IV method provides a general solution to the endogeneity problem, there are important exceptions to its proper use, as when unobservable factors interact nonlinearly with the exogenous regressors, distorting the IV estimates of structural parameters of interest. To deal with this heterogeneity problem (Wooldridge 2002), Eq. (5) may be extended as follows:

$$
y=z_{1}^{\prime} \delta_{y}+\sum x^{\prime} \beta+\sum \alpha v+\sum \theta\left(x^{\prime} v\right)+v_{1}
$$

where $v$ is the residual of an endogenous variable, derived from projection of $x$ on $z ;\left(x^{\prime} v\right)$ is the interaction of the reduced-form residual with the endogenous variable, and $\alpha$ and $\theta$ are parameters to be estimated. The control function variables, i.e., $v$ and $v x$, control for the effects of the unobservable factors that would otherwise distort estimated parameters of a structural equation. The control functions are generalizations of IV estimations and are employed in this analysis to control for the effects of unobservable sources of heterogeneity.

\section{Results and Discussion}

The descriptive statistics show that current proportion of CA adopters out of the total sample is about $57 \%$. The proportion of adopters is higher in Ada'a Chukala (72\%) compared to Bakko Tibe (48 \%). Nonadopters are households that used none of the CA components. Among the adopters, $10 \%$ have used only one component, $75 \%$ have adopted two components, and $15 \%$ have adopted all three components. Nine of the eleven farmers who adopted only a component are applying herbicides, and the other two are using minimum tillage alone. All farmers who have adopted two components are using herbicides associated mainly with minimum tillage and, in few cases, crop residue.

About $87 \%$ of the adopters reported they did plowing in line with CA's philosophy, i.e., minimum soil disturbance. Plowing frequency is higher in Ada'a Chukala for both adopters (1.83/season) and nonadopters (3.26/season) of CA compared to adopters (1.00/ season) and nonadopters (1.96/season) in Bakko Tibe. This is essentially because of the way tef and maize are produced, where the former requires frequent plowing of the land before planting. In Ada'a Chukala, CA adopters have allocated more land 
(1.93 ha/household) to tef than nonadopters (1.64 ha/household). In Bakko Tibe, similarly, CA adopters have allocated more land ( 1.87 ha/household) to maize than nonadopters (1.56 ha/household). In Ada'a Chukala, the productivity per unit land is higher for nonadopters and the productivity per unit human labor is higher for adopters. This might imply that the more frequently you plow, the higher the yield from tef farms. Therefore, it appears that labor investment is still paying in tef production. It was also observed that CA adopters have used more manure, herbicides/pesticides, and inorganic fertilizer compared to nonadopters. In fact, only sample households in Bakko Tibe reported that they have applied manure onto their farm plots. Farmers in Ada'a Chukala have used more (410.5 kg/season) inorganic fertilizer than those in Bakko Tibe (388.8 kg/season). In Bakko Tibe, productivity per unit labor and per unit land is higher for CA adopters.

The distribution of some of the descriptive statistics between adopters and nonadopters (and among the adopters) is presented in Table 1. Highest mean values for man equivalent, age, access to extension (in terms of frequency of contacts), and number of affiliations to social institutions were observed among those who adopted all three components of CA. Maximum mean value for family size, formal education (in years), and land productivity was observed among the respondents who adopted only two components. Farmers who adopted only one component of CA also matched with maximum mean values for total land size, plot size allocated to CA, livestock wealth (both tropical livestock units and number of oxen), and labor productivity. Despite the general lack of any pattern in the values of the descriptors vis-à-vis adoption/not-adoption or number of components adopted, the minimum values of land and labor productivity were observed for farmers who adopted all three components.

\subsection{Adoption of CA Technologies}

The results from the trivariate probit show that the model fits the data well; the Chi-squared value at 17 degrees of freedom is 505.34 ( $p$ value $=.000$ ). It is also evident that our simultaneous modeling of adoption decisions was justified because the off-diagonal values of the error covariance matrix (/atrho $\mathrm{ij}_{\mathrm{ij}}$ ) and the error correlations $\left(\mathrm{rho}_{i j}\right)$ are highly significant (Table 2). Apart from the model justification, the significance of the off-diagonal elements of the covariance matrix shows that there are unobserved heterogeneities that influence the adoption decisions on the different components of CA.

Adoption of minimum tillage did not vary over districts despite the fact that the districts are specialized in maize (Bakko) and tef (Ada'a) production. The decision of using minimum tillage was found to be influenced by family size, access to extension services, and years of formal education. Family size, as the main source of farm labor, was expected to be inversely related to interest in minimum tillage. Frequency of plowing is considered to be an attribute of a good farmer in rural communities of Ethiopia such that farmers always tend to plow more times than less. Similarly, Lanckriet et al. (2014) observed that in northern Ethiopia despite the interest in CA, the agricultural tradition of tilling many times forms an important barrier for CA implementation.

On the other hand, minimum tillage makes farm labor employment less likely than it already is. Thus, if farming households do have enough family labor to plow as frequently as they want, they will apparently be less interested to adopt minimum tillage. Given the difference in the details of the analysis we have done (at component level) and the current state of knowledge on the topic, our result differs from some general reports that CA saves labor (Ehui et al. 1990; FAO 2012), whereas it agrees with empirical research reports (Dick 


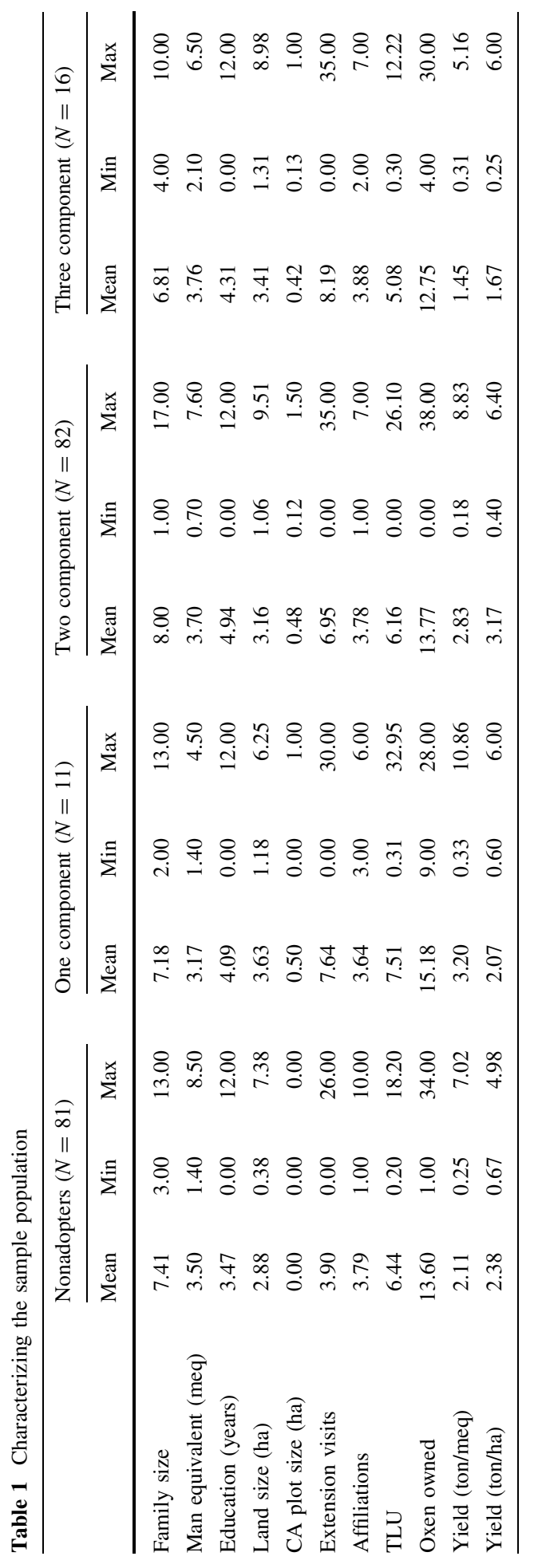


Table 2 Adoption of CA component technologies a, b Imply significance at 1 and $5 \%$ level of statistical error, respectively

\begin{tabular}{|c|c|c|c|}
\hline & $\beta$ & Robust Std. Err. & $P>z$ \\
\hline \multicolumn{4}{|l|}{ Minimum tillage } \\
\hline Woreda & -0.237 & 0.189 & 0.210 \\
\hline Land size & -0.009 & 0.017 & 0.616 \\
\hline Family size & $-0.037^{\mathrm{a}}$ & 0.013 & 0.006 \\
\hline Access extension & $0.037^{\mathrm{b}}$ & 0.018 & 0.037 \\
\hline Education (in years) & $0.064^{\mathrm{b}}$ & 0.032 & 0.045 \\
\hline Leased in land (dummy) & -0.158 & 0.210 & 0.454 \\
\hline \multicolumn{4}{|l|}{ Crop residue use } \\
\hline Woreda & $-2.326^{\mathrm{a}}$ & 0.428 & 0.000 \\
\hline Access extension & -0.004 & 0.026 & 0.887 \\
\hline Livestock wealth (TLU) & -0.014 & 0.036 & 0.688 \\
\hline Fertile land (dummy) & -0.074 & 0.280 & 0.792 \\
\hline Education (in years) & 0.058 & 0.038 & 0.128 \\
\hline Age of $\mathrm{HH}$ head & -0.133 & 0.093 & 0.151 \\
\hline \multicolumn{4}{|l|}{ Use of herbicides } \\
\hline Woreda & $-0.714^{\mathrm{a}}$ & 0.184 & 0.000 \\
\hline Access extension & $0.059^{\mathrm{a}}$ & 0.015 & 0.000 \\
\hline Access to credit (dummy) & 0.037 & 0.080 & 0.648 \\
\hline Education (in years) & $0.077^{\mathrm{b}}$ & 0.037 & 0.037 \\
\hline Leased in land (dummy) & -0.018 & 0.189 & 0.923 \\
\hline /atrho $_{21}$ & $0.666^{\mathrm{a}}$ & 0.187 & 0.000 \\
\hline /atrho $_{31}$ & $3.699^{\mathrm{a}}$ & 0.474 & 0.000 \\
\hline /atrho $_{32}$ & $0.671^{\mathrm{a}}$ & 0.197 & 0.001 \\
\hline $\mathrm{rho}_{21}$ & $0.582^{\mathrm{a}}$ & 0.123 & 0.000 \\
\hline $\mathrm{rho}_{31}$ & $0.999^{\mathrm{a}}$ & 0.001 & 0.000 \\
\hline $\mathrm{rho}_{32}$ & $0.586^{\mathrm{a}}$ & 0.129 & 0.000 \\
\hline Number of obs. & 190 & & \\
\hline Wald $\mathrm{Chi}^{2}(17)$ & 505.34 & Prob $>\mathrm{Chi}^{2}$ & 0000 \\
\hline Log pseudolikelihood & -198.62102 & & \\
\hline
\end{tabular}

and van Doren 1985; Francis and Knight 1993; Griffith et al. 1988; Mesfine et al. 2005) that have shown that CA does not necessarily improve land and labor productivity.

On the contrary, access to extension services and years of education positively influence adoption decision of minimum tillage. The role of CA-based extension is self-explanatory, while education similarly enlightens the farming community with the importance of conservation practices in general and minimum disturbance of the soil in particular. The adoption decision of crop residues seems to be less influenced by the exogenous factors included in the model. Only the district dummy significantly influenced the decision. This result implies that the difference in crops-as the two districts grow predominantly two different crops-is the main driving force behind the decision to use crop residues. Although statistically insignificant, livestock ownership, perceived level of plot fertility, and education have the expected positive influence, whereas access to extension seems to be negatively related to crop residue use as part of conservation agriculture. 
In Ethiopia, extension on CA also advocates use of chemical herbicides (primagram and roundup), as weed control is an important challenge at the early stages of CA. Farmers in Ada' a Chukala (tef growers) are more likely to use chemical herbicides than farmers in Bakko Tibe-the maize-growing area. This is apparently because tef is more susceptible to weed (and more profitable) than maize-making investment on herbicides worthwhile. Access to extension services was also found to be positively influencing the use of the herbicides. Formal education significantly influences the decision to use herbicides.

Generally, farmers in Ada'a Chukala seem to be more inclined to adopt the different components of CA. The district grows tef, and tef is a very labor-intensive and weedsusceptible crop. Tef growing farmers would therefore tend to be more likely to adopt minimum tillage and herbicides, the later essentially to reduce labor drudgery. Also, use of commercial herbicides is financially justifiable as the crop consistently fetches high prices in the market. Access to extension has also been positive and significant in influencing adoption decision of herbicides. The positive influence of extension is expected, as there has been continuous flow of information on CA from SG-2000 and the Ministry of Agriculture. The extension information on CA makes farmers aware of the important components of CA technologies and how to apply them, as well as the benefits associated with them. Further, extension services reduce the uncertainty associated with adopting complex technologies (Pannell et al. 2006). Similarly, formal education has consistently been positively related to the adoption of all components of CA, because education enhances the knowledge base for adoption (Ali and Abdulai 2010; Becerril and Abdulai 2010).

\subsection{Impact of CA Technologies}

The impact of components of CA on land and labor productivity was estimated with control function technique (Imbens and Wooldridge 2009). The control function was employed to account for the potential endogeneity that can happen between the decisions to adopt the different components of CA that might encourage farmers to demand higher number of contacts with agricultural extension agents.

The results from land productivity estimations (Table 3) show that Bakko (maize growing) farmers enjoy better land productivity than tef growing farmer of Ada'a. This is simply because the absolute yield per unit of land for maize is much higher than that of tef. Herbicide use was the only component whose adoption increases land productivity. The other two components (minimum tillage and crop residue use) were statistically insignificant.

Male-headed households and households with higher livestock wealth also enjoy significantly higher land productivity than female-headed and those with less livestock households, respectively, everything else held constant. Labor power endowment (in terms of man equivalent) was negatively related to land productivity. This is because land (fixed asset) is so limited that as labor increases productivity per unit of land decreases.

The labor productivity model also shows that labor productivity is significantly higher in Bakko Tibe as compared to Ada'a Chukala for the same reason as for land productivity (Table 4). Interestingly, none of the CA components influenced labor productivity. Nonetheless, minimum tillage and crop residue use seemed to be negatively related to family labor productivity. Increase in farmland size increases the productivity of labor possibly through employment of surplus family labor.

Research reports from on-station and on-farm trials of different land preparation methods and their effect on yield have shown similar results. Predominantly, the results are 
Table 3 Impact of conservation agriculture on land productivity

\begin{tabular}{lclrl}
\hline Yield (ton)/ha & \multicolumn{1}{l}{ Robust std. err. } & \multicolumn{1}{l}{$t$} & $P>t$ \\
\hline Woreda & $2.030^{\mathrm{a}}$ & 0.255 & 7.970 & 0.000 \\
Minimum tillage & 0.246 & 0.234 & 1.050 & 0.295 \\
Crop residue use & -0.262 & 0.232 & -1.130 & 0.260 \\
Herbicide use & $0.845^{\mathrm{a}}$ & 0.280 & 3.020 & 0.003 \\
Sex & $0.863^{\mathrm{a}}$ & 0.330 & 2.610 & 0.010 \\
Age & 0.105 & 0.089 & 1.180 & 0.241 \\
Livestock wealth (TLU) & $0.042^{\mathrm{b}}$ & 0.020 & 2.080 & 0.039 \\
Man equivalent & $-0.184^{\mathrm{a}}$ & 0.064 & -2.870 & 0.005 \\
Education in years & 0.041 & 0.030 & 1.350 & 0.179 \\
Quantity of fertilizer & -0.010 & 0.027 & -0.380 & 0.708 \\
Quantity of chemical used & 0.027 & 0.070 & 0.390 & 0.698 \\
Access to credit (dummy) & 0.111 & 0.199 & 0.560 & 0.577 \\
Number of affiliations & 0.064 & 0.068 & 0.940 & 0.351 \\
Intensity of CA use & -0.168 & 0.315 & -0.530 & 0.595 \\
Residual of model & $0.249^{\mathrm{a}}$ & 0.076 & 3.280 & 0.001 \\
Residual X extension & 0.005 & 0.024 & 0.230 & 0.820 \\
Constant & -0.393 & 0.522 & -0.750 & 0.453 \\
Number of obs. & 190 & & & \\
$F(16,173)$ & 17.81 & & & \\
Prob $>F$ & 0.0000 & & & \\
$R^{2}$ & 0.5591 & & & \\
\hline
\end{tabular}

a, b Imply significance at 1 and $5 \%$ level of statistical error, respectively

that minimum/reduced tillage does not significantly increase productivity of the cereal crops on which the experiments were conducted. After comparing broad bed furrows, green manure, ridge and furrow, and reduced tillage, Erkossa et al. (2006) reported that reduced tillage did not have a statistically significant effect on tef and wheat grain yield compared to farmers' way of land preparation. After comparing conventional tillage (CT) [with a minimum of three tillage operations and removal of crop residues], terwah [that was similar to CT except that contour furrows were included at 1.5-m intervals], and derdero [which consists of permanent raised beds with a furrow and bed system, retention of $30 \%$ of standing crop residues, and zero tillage on the top of the bed] for three years, Araya et al. (2010) reported that grain yield was significantly lower in derdero [which is considered equivalent to $\mathrm{CA}$ ] under tef, probably due to the high sensitivity of tef to weeds. Based on the same trial but with glyphosate (broad-spectrum systemic herbicide) application starting from the third year at $2 \mathrm{~L} / \mathrm{ha}^{3}$ before planting to control pre-emergent weed in terwah and derdero, Araya et al. (2012) reported observing improvements in crop yield [with higher standard deviation] although a period of at least five years of cropping was required before the difference became significant. Similarly, Tulema et al. (2008) reported results of a field experiment that compared zero tillage, minimum tillage, conventional tillage, and broad bed furrows (BBF) on the yield of tef for 2 years in Vertisol and Nitisol.

3 "ha" stands for hectare which is equivalent to 0.01 square kilometer $\left(\mathrm{km}^{2}\right)$. 
Table 4 Impact of conservation agriculture on labor productivity

\begin{tabular}{lclrl}
\hline Yield (ton)/meq & $\beta$ & Robust std. err. & $t$ & $P>t$ \\
\hline Woreda & $1.597^{\mathrm{a}}$ & 0.291 & 5.490 & 0.000 \\
Minimum tillage & -0.069 & 0.673 & -0.100 & 0.918 \\
Crop residue use & -0.504 & 0.317 & -1.590 & 0.113 \\
Herbicide use & 0.754 & 0.591 & 1.280 & 0.204 \\
Land size owned & $0.446^{\mathrm{a}}$ & 0.103 & 4.340 & 0.000 \\
Sex & -0.153 & 0.835 & -0.180 & 0.855 \\
Age & $-0.271^{\mathrm{b}}$ & 0.118 & -2.300 & 0.022 \\
Number of oxen & -0.022 & 0.017 & -1.310 & 0.191 \\
Education in years & 0.031 & 0.040 & 0.780 & 0.437 \\
Fertile land (dummy) & 0.041 & 0.266 & 0.150 & 0.877 \\
Quantity of chemical used & 0.057 & 0.102 & 0.560 & 0.577 \\
Access to credit (dummy) & 0.049 & 0.247 & 0.200 & 0.842 \\
Intensity of CA use & -0.343 & 0.466 & -0.740 & 0.462 \\
Residual of model & 0.041 & 0.133 & 0.310 & 0.756 \\
Residual X extension & 0.042 & 0.048 & 0.890 & 0.377 \\
Constant & 0.574 & 0.945 & 0.610 & 0.544 \\
Number of obs. & 190 & & & \\
$F(15,174)$ & 8.73 & & & \\
Prob $>F$ & 0.000 & & & \\
$R^{2}$ & 0.3913 & & & \\
\hline
\end{tabular}

a, b Imply significance at 1 and $5 \%$ level of statistical error, respectively

The results indicated that there was no any difference in tef biomass and grain yields observed between the treatments on both soils in the first year. In the second year, however, yield was lower in the zero tillage treatment as compared to the other treatments on Nitisols and BBF gave the highest yield on Vertisols. It was also indicated that more than twice as much grass weed was observed on zero tillage treatment as compared to the BBF treatment on both soils. Zero tillage gave the lowest gross margin on both soils, whereas BBF gave the highest gross margin (Tulema et al. 2008).

When put into a broader context, the results we are reporting are rather comparable to the findings of comprehensive meta-analyses (Corbeels et al. 2014; Nyamangara et al. 2014; Rusinamhodzi et al. 2011). Long-term application ( $>3$ years) of no-tillage is known to reduce grain yield especially when not complemented with mulching (Corbeels et al. 2014; Nyamangara et al. 2014). The lower grain yield under no-tillage compared to farmers' practice was attributed to low soil aggregate stability, high soil penetration resistance, surface soil slaking, and high water runoff (Baudron et al. 2012; Rusinamhodzi et al. 2011). Insignificant or negative effects of mulching on grain yield within the auspices of conservation agriculture are not unique for our study areas. A combination of no-tillage and mulching was found to have no effect on maize grain yields in the first ten years of experiments and even negative effects later on under rainfed conditions (Rusinamhodzi et al. 2011). A meta-analysis on mulching on maize in Zimbabwe reported no overall effect on grain yield as well (Nyamangara et al. 2014). 


\section{Conclusions}

In Ethiopia, a country where natural resources degradation is very serious and a worsening problem for livelihoods, promoting soil conservation techniques such as CA is an important intervention toward achieving food security through sustainable farming. Although the adoption level is quite encouraging, relatively few farmers are adopting all the three components of CA which SG-2000 has been promoting. In any case, simple comparisons based on land and labor productivities do not justify adoption of all three components.

The analysis of the adoption decisions of the different components has also shown consistently the importance of location, access to extension services, and formal education. The importance of location (or production system)-specific interventions, timely and adequate agricultural extension services, applicable and relevant formal education to enhance the use of improved technologies and hence sustainability of agriculture can hardly be overemphasized.

This study has also shown that use of herbicides, which is virtually a component of CA in Ethiopia's context, increases productivity per unit of land. Provided that appropriate calibration and efficacy studies are conducted, it is appropriate to encourage widespread use of herbicides as this relieves farmers the burden of extensively cultivating limited cropland which is becoming less and less available.

Finally, adoption and impact assessments of CA and similar technologies should further be investigated to continuously avail information to policy makers and technology users. These assessments need to be comprehensive and employ the appropriate methods to facilitate understanding and use of the information to be generated. This paper contributes in this regard by showing the applicability of the trivariate probit model and the control function approach in conducting such assessments.

Acknowledgments Funding was provided by Nippon International, and International Maize and Wheat Improvement Center (CIMMYT).

\section{References}

Ali, A., \& Abdulai, A. (2010). The adoption of genetically modified cotton and poverty reduction in Pakistan. Journal of Agricultural Economics, 61(1), 175-192. doi:10.1111/j.1477-9552.2009.00227.x.

Araya, T., Cornelis, W. M., Nyssen, J., Bram Govaerts, Gebregziabher, T., Oicha, T., et al. (2010). Impact of conservation agriculture on runoff, soil loss and crop yield on a Vertisol in the northern Ethiopian highlands. Paper presented at the World Congress of Soil Science, Soil Solutions for a Changing World, Brisbane, Australia.

Araya, T., Cornelis, W. M., Nyssen, J., Govaerts, B., Getnet, F., Bauer, H., et al. (2012). Medium-term effects of conservation agriculture based cropping systems for sustainable soil and water management and crop productivity in the Ethiopian highlands. Field Crops Research, 132, 53-62. doi:10.1016/j.fcr. 2011.12.009.

Araya, T., Nyssen, J., Govaerts, B., Deckers, J., \& Cornelis, W. M. (2015). Impacts of conservation agriculture-based farming systems on optimizing seasonal rainfall partitioning and productivity on vertisols in the Ethiopian drylands. Soil and Tillage Research, 148, 1-13. doi:10.1016/j.still.2014.11. 009.

Baudron, F., Tittonell, P., Corbeels, M., Letourmy, P., \& Giller, K. E. (2012). Comparative performance of conservation agriculture and current smallholder farming practices in semi-arid Zimbabwe. Field Crops Research, 132, 117-128. doi:10.1016/j.fcr.2011.09.008. 
Becerril, J., \& Abdulai, A. (2010). The impact of improved maize varieties on poverty in Mexico: A propensity score matching approach. World Development, 38, 1024-1035. doi:10.1016/j.worlddev. 2009.11.017.

Belderbos, R., Carree, M., Diederen, B., Lokshin, B., \& Veugelers, R. (2004). Heterogeneity in R\&D cooperation strategies. International Journal of Industrial Organization, 22, 1237-1263. doi:10.1016/j. ijindorg.2004.08.001.

Berry, L. (2003). Land degradation in Ethiopia: its extent and impact: Commissioned by the Global Mechanism with World Bank support.

Brady, N. C., \& Weil, R. R. (2007). The nature and properties of soils (14th ed.). Upper Saddle River, NY: Prentice Hall.

Cappellari, L., \& Jenkins, S. P. (2003). Multivariate probit regression using simulated maximum likelihood. The Stata Journal, 3(3), 278-294.

Chib, S., \& Greenberg, E. (1998). Analysis of multivariate probit models. Biometrika, 85(2), 347-361.

Corbeels, M., Sakyi, R. K., Kühne, R. F., \& Whitbread, A. (2014). Meta-analysis of crop responses to conservation agriculture in sub-Saharan Africa. CCAFS Report. Copenhagen. Denmark: CGIAR Research Program on Climate Change, Agriculture and Food Security (CCAFS).

Dick, W. A., \& van Doren, D. M. (1985). Continuous tillage and rotation combinations effects on corn, soybean and oat yields. Agronomy Journal, 77(3), 459-465.

Dumanski, J., Peiretti, R., Benetis, J., McGarry, D., \& Pieri, C. (2006). The Paradigm of Conservation Tillage. Paper presented at the World Association of Soil and Water Conservation.

EEA. (2006). Evaluation of the Ethiopian agricultural extension with particular emphasis on participatory demonstration and training extension system (PADETS). Addis Ababa: Ethiopian Economics Association.

Ehui, S. K., Kang, B. T., \& Spencer, D. S. C. (1990). Economic analysis of soil erosion effects in alley cropping, no-till and bush fallow systems in south western Nigeria. Agricultural Systems, 34(4), 349-368.

Erkossa, T., Stahr, K., \& Gaiser, T. (2006). Soil tillage and crop productivity on a Vertisol in Ethiopian highlands. Soil and Tillage Research, 85(1-2), 200-211. doi:10.1016/j.still.2005.01.009.

FAO. (2001). The economics of conservation agriculture. Rome, Italy: Food and Agriculture Organization of the United Nations (FAO).

FAO. (2012). Conservation agriculture. Retrieved April 30, 2012, from http://www.fao.org/ag/ca/.

FAO. (2016). What is conservation agriculture? Retrieved 17 April, 2016, from http://www.fao.org/ag/ca/ 1a.html.

Francis, G. S., \& Knight, T. L. (1993). Long term effects of conventional and zero tillage on selected soil properties and crop yield in Canterbury, New Zealand. Soil and Tillage Research, 26(3), 193-210.

Garcia-Torres, L., Benites, J., Martinez-Vilela, A., \& Holgado-Cabrera, A. (2003). Conservation agriculture: Environment, farmers experiences, innovations, socio-economy, policy. Dordrecht, The Netherlands; Boston, Germany; London, UK: Kluwer Academia Publishers.

Gemeda, A., Aboma, G., Verkuijl, H., \& Mwangi, W. (2001). Farmers' maize seed systems in Western Oromia, Ethiopia. El Batan, Mexico: International Maize and Wheat Improvement Center (CIMMYT) and Ethiopian Agricultural Research Organization (EARO).

Giller, K. E., Witter, E., Corbeels, M., \& Tittonell, P. (2009). Conservation agriculture and smallholder farming in Africa: The heretics' view. Field Crops Research, 114(1), 23-34. doi:10.1016/j.fcr.2009.06. 017.

Greene, W. H. (2008). Econometric analysis (6th ed.). Upper Saddle River, NY: Prentice Hall.

Griffith, D. R., Kladivko, E. J., Mannering, J. V., West, T. D., \& Parsons, S. D. (1988). Long-term tillage and rotation effects on corn growth and yield on high and low organic matter, poorly drained soils. Agronomy Journal, 80(4), 599-605.

Haggblade, S., \& Tembo, G. (2003). Conservation farming in Zambia. EPTD Discussion Paper, 108. Washington, DC: International Food Policy Research Institute.

Hawando, T. (2000). Desertification in Ethiopian highlands. In N. C. Aid (Ed.), RALA Report. Norwegian Church AID: Addis Ababa.

Imbens, G., \& Wooldridge, J. M. (2009). Recent developments in the econometrics of program evaluation. Journal of Economic Literature, 47(1), 5-86.

Ito, M., Matsumoto, T., \& Quinones, M. (2007). Conservation tillage in Sub-Saharan Africa: The experience of Sasakawa Global 2000. Crop Protection, 26(3), 417-423.

Jolejole-Foreman, M. C., Baylis, K. R., \& Lipper, L. (2012). Land degradation's implications on agricultural value of production in Ethiopia: A look inside the bowl. Paper presented at the International Association of Agricultural Economists (IAAE) Triennial Conference, Foz do Iguacu, Brazil. http:// ageconsearch.umn.edu/bitstream/126251/2/IAAE2012_JForemanBaylisLipper.pdf. 
Karanja, D., Renkow, M., \& Crawford, E. (2003). Welfare effects of maize technologies in marginal and high potential regions of Kenya. Agricultural Economics, 29(3), 331-341.

Kassa, H. (2003). Livestock and livelihood security in the Harar highlands of Ethiopia: Implications for research and development. ( $\mathrm{PhD}$ Thesis), Swedish University of Agricultural Sciences, Uppsala, Sweden (388).

Kassie, M., Zikhali, P., Manjur, K., \& Edwards, S. (2009). Adoption of sustainable agriculture practices: Evidence from a semi-arid region of Ethiopia. Natural Resources Forum, 33(3), 189-198.

Knowler, D., \& Bradshaw, B. (2007). Farmers' adoption of conservation agriculture: A review and synthesis of recent research. Food Policy, 32(1), 25-48.

Lanckriet, S., Araya, T., Derudder, B., Cornelis, W. M., Bauer, H., Govaerts, B., et al. (2014). Toward practical implementation of conservation agriculture: A case study in the May Zeg-Zeg Catchment (Ethiopia). Agroecology and Sustainable Food Systems, 38(8), 913-935. doi:10.1080/21683565.2014. 917143.

Leake, A. R. (2003). Integrated pest management for conservation agriculture. In L. Garcia-Torres, J. Benites, A. Martinez-Vilela, \& A. Holgado-Cabrera (Eds.), Conservation agriculture: environment, farmers experiences, innovations, socio-economy, policy (pp. 271-279). Dordrecht, The Netherlands; Boston, Germany; London, UK: Kluwer Academia Publishers.

Matsumoto, T., Plucknett, D., \& Mohamed, K. (2004). Evaluation of the Sasakawa Global 2000 Program in Ethiopia, 1992-2002. Sasakawa Africa Association.

Mazvimavi, K., \& Twomlow, S. (2009). Socioeconomic and institutional factors influencing adoption of conservation farming by vulnerable households in Zimbabwe. Agricultural Systems, 101(1-2), 20-29.

Mesfine, T., Abebe, G., \& Al-Tawaha, A.-R. M. (2005). Effect of reduced tillage and crop residue ground cover on yield and water use efficiency of sorghum (Sorghum bicolor (L.) Moench) under semi-arid conditions of Ethiopia. World Journal of Agricultural Sciences, 1(2), 152-160.

Mowo, J., \& Kiwia, A. (2009). Brief report on the conservation agriculture with trees. In Side event at the 2nd World Agroforestry Congress, August 23-28, 2009, UNEP, Nairobi.

Nyamangara, J., Nyengerai, K., Masvaya, E. N., Tirivavi, R., Mashingaidze, N., Mupangwa, W., et al. (2014). Effect of conservation agriculture on maize yield in the semi-arid areas of Zimbabwe. Experimental Agriculture, 50(02), 159-177. doi:10.1017/S0014479713000562.

Oicha, T., Cornelis, W., Verplancke, H., Nyssen, J., Govaerts, B., Behailu, M., et al. (2010). Short-term effects of conservation agriculture on Vertisols under tef (Eragrostis tef (Zucc.) Trotter) in the northern Ethiopian highlands. Soil \& Tillage Research, 106, 294-302. doi:10.1016/j.still.2009.12.004.

Pannell, D. J., Marshall, G. R., Barr, N., Curtis, A., Vanclay, F., \& Wilkinson, R. (2006). Understanding and promoting adoption of conservation practices by rural landholders. Australian Journal of Experimental Agriculture, 46(11), 1407-1424.

Rockstrom, J., Kaumbutho, P., Mwalley, J., Nzabi, A., Temesgen, M., Mawenya, L., et al. (2009). Conservation farming strategies in East and Southern Africa: Yields and rain water productivity from onfarm action research. Soil and Tillage Research, 103(1), 23-32.

Rusinamhodzi, L., Corbeels, M., Wijk, M. T., Rufino, M. C., Nyamangara, J., \& Giller, K. E. (2011). A meta-analysis of long-term effects of conservation agriculture on maize grain yield under rain-fed conditions. Agronomy for Sustainable Development, 31(4), 657-673. doi:10.1007/s13593-011-0040-2.

Shames, S. (2006). A financial analysis of conservation tillage as a solution to land degradation on small farms in Ethiopia (Bulletin 3, Forum for Social Science). Ethiopia: Addis Ababa.

Tamene, L., \& Vlek, P. L. G. (2008). Soil erosion studies in Northern Ethiopia. In A. K. Braimoh \& P. L. G. Vlek (Eds.), Land use and soil resources (pp. 73-100). Dordrecht: Springer.

Train, K. (2003). Discrete choice models with simulation. Cambridge: Cambridge University Press.

Tulema, B., Aune, J. B., Johnsen, F. H., \& Vanlauwe, B. (2008). The prospects of reduced tillage in tef (Eragrostis tef Zucca) in Gare Arera, West Shawa Zone of Oromiya, Ethiopia. Soil and Tillage Research, 99(1), 58-65. doi:10.1016/j.still.2007.12.001.

Wooldridge, J. M. (2002). Econometric analysis of cross section and panel data. Cambridge, MA: The MIT Press. 